\title{
Pengaruh Dosis Kompos dan Pupuk KCl Terhadap Pertumbuhan dan Hasil Tanaman Talas (Colocasia esculenta L. Schott var. Antiquorum)
}

\section{The Effect Of Compost and KCl fertilizer on the Growth and Yield of Taro Plants (Colocasia esculenta L. Schott var. Antiquorum)}

\author{
Iswardani $^{1}$, Marai Rahmawati ${ }^{1}$ Mardhiah Hayati* $^{* 1}$ \\ ${ }^{1}$ Mahasiswa Program Studi Agroteknologi, Fakultas Pertanian, Universitas Syiah Kuala
}

\begin{abstract}
Abstrak. Talas (Colocasia esculenta L. Schott var. Antiquorum) merupakan tanaman pangan yang dapat dikonsumsi oleh masyarakat. Kompos adalah bahan organikk yang dapat memperbaiki sifat fisika, biologi dan kimia tanah. Pupuk $\mathrm{KCl}$ dapat membantu dalam pembesaran umbi. Tujuan penelitian ini adalah untuk mengetahui pengaruh pemberian dosis kompos dan pupuk $\mathrm{KCl}$ serta interaksi keduanya terhadap pertumbuhan dan hasil tanaman talas. Penelitian ini dilakukan di Kebun Percobaan II dan Laboratorium Fisiologi Tumbuhan Fakultas Pertanian Universitas Syiah Kuala Darussalam Banda Aceh, yang dilaksanakan pada bulan Maret sampai Agustus 2018. Rancangan yang digunakan dalam penelitian ini adalah Rancangan Acak Kelompok Pola Faktorial 3 x 3 dengan 3 ulangan. Adapun faktor yang diteliti adalah dosis kompos dengan 3 taraf yaitu 20, 30 dan 40 ton ha ${ }^{-1}$ dan dosis pupuk $\mathrm{KCl}$ dengan 3 taraf yaitu 200,300, dan $400 \mathrm{~kg} \mathrm{ha}^{-1}$. Parameter yang diteliti yaitu tinggi tanaman dan jumlah daun pada umur 2, 4, 6, 8, 10, dan 12 MST, diameter batang pada umur 12 MST, bobot berangkasan basah, bobot berangkasan kering, bobot umbi basah, jumlah umbi dan diameter umbi. Data yang diperoleh dianalisis dengan menggunakan uji F, dilanjutkan dengan uji BNT pada taraf 5\%. Hasil penelitian menunjukkan bahwa dosis kompos berpengaruh nyata terhadap jumlah daun tanaman talas pada umur 2 dan 10 MST, bobot umbi segar, dan jumlah umbi tanaman talas. Pertumbuhan dan hasil tanaman talas terbaik dijumpai pada dosis kompos 40 ton $\mathrm{ha}^{-1}$. Dosis pupuk $\mathrm{KCl}$ berpengaruh nyata terhadap tinggi tanaman talas umur 2 MST, jumlah daun tanaman talas umur 4 MST, bobot berangkasan basah, bobot umbi basah dan jumlah umbi tanaman talas,. Pertumbuhan tanaman talas terbaik dijumpai pada dosis pupuk KCl $300 \mathrm{~kg} \mathrm{ha}^{-1} \mathrm{dan}$ hasil tanaman talas terbaik dijumpai pada pada dosis pupuk $\mathrm{KCl} 400 \mathrm{~kg} \mathrm{ha}^{-1}$.
\end{abstract}

Kata Kunci: Dosis, $\mathrm{KCl}$, Kompos, Talas

\begin{abstract}
Talas (Colocasia esculenta L. Schott var. Antiquorum) is a food crop that can be used by the community. $\mathrm{KCl}$ fertilizer can help in enlarging tubers. The purpose of this study was to determine the effect of fertilizer and $\mathrm{KCl}$ fertilizers and interactions on growth and yield of taro plants. This research was conducted at Experimental Garden II and Laboratory of Plant Physiology, Faculty of Agriculture, Syiah Kuala Darussalam University, Banda Aceh, which was held from March to August 2018. The design used in this study was a Factorial 3 x 3 Randomized Group Design with 3 replications. The factors examined were compost doses with 3 levels, namely 20, 30 and 40 tons ha-1 and $\mathrm{KCl}$ fertilizer dosages with 3 levels, namely 200, 300, and $400 \mathrm{~kg}$ ha1. The parameters studied were plant height and number of leaves at 2, 4, 6, 8, 10, and $12 \mathrm{MST}$, stem diameter at age 12 MST, wet weighted weight, dry weighted weight, wet tuber weight, number of tubers and tuber diameter. The data obtained were analyzed using the F test, followed by the LSD test at the level of 5\%. The results showed that compost dosage was as significant as the number of leaves of taro plants at age 2 and 10 MST, weight of fresh bulbs, and the number of taro tubers. Growth and yield of taro plants at a temperature level of 40 tons ha- 1 . The results showed that the dose of $\mathrm{KCl}$ fertilizer significantly affected the height of taro plants aged 2 MST, the number of leaves of taro plants aged $4 \mathrm{MST}$, wet weighted weight, weight of tubers and the number of taro tubers, and not even on plant heights of 4, 6 8, 10, and 12 MST, number of leaves aged 2, 6, 8, 10 and 12 MST, stem diameter, dry weight, and tuber diameter of taro plants. The best growth of taro plants when the fertilizer dose of $\mathrm{KCl} 300 \mathrm{~kg}$ ha-1 fertilizer and the results of the best taro plants found at the time of heating $\mathrm{KCl} 400 \mathrm{~kg}$ ha-1 fertilizer.
\end{abstract}

Keyword: Dose, $\mathrm{KCl}$, Kompos, Taro

\section{PENDAHULUAN}

\section{Latar Belakang}

Talas merupakan tanaman pangan yang asalnya dari Asia Selatan (India), menyebar ke Cina, Jepang, dan ke daerah Asia Tenggara lainnnya (Purwono dan Heni, 2007; Prana, 
2007). Pada umumnya tanaman talas banyak ditanaman di wilayah Asia, Pasifik, Amerika Tengah, dan Afrika. Talas adalah suatu tanaman pangan penting di kepulauan Pasifik. Diversifikasi pangan adalah suatu program untuk mengganti lebih dari satu jenis komoditi yag dikonsumsi agar masyarakat tidak terfokus untuk mengonsumsi satu jenis makanan pokok saja (Hanafie dan Rita, 2003).

Menurut Badan Ketahanan Pangan (2015) jumlah konsumsi pangan penduduk Indonesia untuk umbi-umbian tahun 2012-2014 mengalami penurunan yaitu pada tahun 2012 yaitu 33,9 g kapita hari ${ }^{-1}$ menjadi 31,8 g kapita hari ${ }^{-1}$ pada tahun 2014. Angka tersebut masih jauh lebih rendah dibandingkan konsumsi padi-padian yang mencapai 295,9 g per kapitahari ${ }^{-1}$ untuk tahun 2015. Menurut Corwin (2007), hal tersebut disebabkan oleh masyarakat Indonesia masih bergantung pada padi.

Umbi talas sangat berpotensi untuk memenuhi kebutuhan pangan masyarakat Indonesia, karena mempunyai produksi yang tinggi yaitu dapat mencapai 28 ton $\mathrm{ha}^{-1}$, dengan investasi tanam yang lebih kecil dibandingkan dengan membuka areal sawah padi (Budiyanto, 2009). Umbi talas sangat berguna sebagaii sumber makanan pokok alternatif sehat dan aman, karena memiliki kandungan vitamin, kalori dan serat, karbohidrat serta gula reduksi sediikit (Biottrop, 2007). Jepang memerlukan pasokan umbi talas dari negara lain untuk mencukupi kebutuhan negaranya, Indonesia adalah salah satu Negara pemasok umbi talas yang di ekspor ke Jepang (Biotrop, 2013).

Satoimo (Colocasia escuelenta L. Schott var. Antiquorum) merupakan jenis talas yang memiliki ukuran umbi kecil (small corm taro) yang disebut juga sebagai talas jepang atau talas safira yang diperdagangkan secara internasional. Jumlah produksi umbi talas di Jepang lebih rendah jika dibandingkan dengan kebutuhan negara tersebut, yaitu kebutuhan mencapai 360 ribu ton tahun ${ }^{-1}$ namun yang hanya dapat di produksi sebanyak 110 ribu ton tahun ${ }^{-1}$. Keadaan seperti ini membuat terbukanya peluang ekspor Indonesia ke negara tersebut. (Biotrop, 2013).

Indonesia hannya dapat menghasilkan umbi talaas sebnyak 25 ton bulan ${ }^{-1}$ (300 ton tahun $^{-1}$ ) yang berarti 39,7 ribu ton tahun ${ }^{-1}$ lebih rendah dari jumlah yang diinginkan, mencapai 40 ribu ton tahun $^{-1}$. Hal ini diakibatkan oleh manajemen petani terhadap tanaman dan kesuburann lahaan yang mengakibatkan produksi umbi talas di Indonesia menjadi rendah (Hidayat, 2006). Kompos adalah salah satu pupuk organik yang dapat digunakan sebagai penyedia unsure hara bagi tanah.

Kompos adalah pupuk organikk yang diperoleh dengan memanfaatkan limbah peternakan dan limbah pertanian (Mullyono, 2014). limbah pertanian yang dapat digunakan adalah semua bagian vegetatif tanaman (Suwahyono, 2014). Kompos dapat berasal dari sisa tanaman padi, salah satu bahan kompos yang dapat digunakan yaitu arang sekam. Kandungan arang sekam yaitu N 0,32\%, P 15\%, K $31 \%$, Ca 0,95\%, dan Fe 180 ppm, Zn 14,1 ppm dan $\mathrm{pH}$ 6,8. Arang sekam memiliki tekstur ringan (berat jenis $0,2 \mathrm{~kg} \mathrm{l}^{-1}$ ) sirkulasi udara tinggi, kapasitas menahan air tinggi, berwarna kehitaman, mengakibatkan cahaya matahari dapat di absorpsi dengan baik (Wuryaningsih dan Sutater, 1996). Prihmantoroo dan Indriaani (2003) menyatakan bahwa arang sekam bersifat gampang mengikat air, mempunyai porositas yang baik, ringan, tidak mudah menggumpal, hargnya relatif murah, dan mudah di dapat.

Tanaman talas yang diberi kommpos sampah kota dengan dossis 7,56 ton ha ${ }^{-1}$ akan dapat menghasilkan komponen pertumbuhan hasil yang lebih baik dan panen umbi hektar ${ }^{-1}$ yang lebih tinggi, yaitu sebesar 12,77 ton $\mathrm{ha}^{-1}$ (Nagano dan Suminarti, 2016). Berdasarkan penelitian Pradana (2016), aplikasi kompos jerami padi sebanyak 22,5 ton ha ${ }^{-1}$ menghasilkan 
bobot umbi ubi jalar sebanyak $311,70 \mathrm{~g}$ umbi $^{-1}$, tidak berbeda nyata dengan pemberian kompos jerami padi sebanyak 15 ton $\mathrm{ha}^{-1}$ yang menghasilkan 255,57 $\mathrm{g} \mathrm{umbi}^{-1}$. Hasil penelitian Sitompul (2018), pertumbuhan dan hasil tanaman talas terbaik dijumpai pada pemberiann pupuk kandang sebanyak 30 ton $\mathrm{ha}^{-1}$, yang menghasilkan rata-rata bobot umbi $390 \mathrm{~g}$ tanaman $^{-1}$.

Tanaman talas cukup responsif terhadap pemupukan $\mathrm{K}$ yang berperan dalam proses pembesaran umbi (Onwueme, 1978). Pupuk kalium dapat menaikkan jumlah umbi tanaman ${ }^{-1}$, sebagai translokasii (pemindahan) gula pada pembentukann pati dan protein, membanntu prosess membuka dan menutup stomata, efisiensi dalam menggunakan air (ketahanan terhadap kekeringan), memperluas akar serta dapat meningkatkan ketahaanan tanamaan terhadap gagguan hama dan penyakit (Novizan, 2001). Penggunaan pupuk dengan dosis Urea, SP36, dann $\mathrm{KCl}$ masing-masing sebanyak $280 \mathrm{~kg} \mathrm{ha}^{-1}, 170 \mathrm{~kg} \mathrm{ha}^{-1}$ dan $400 \mathrm{~kg} \mathrm{ha}^{-1}$ berpengaruh nyata terhadap tinggi tanaman (4 MST) dan bobot umbi tanaman talas. Penggunaan pupuk Kalium sebanyak $400 \mathrm{~kg} \mathrm{ha}^{-1}$ menghasilkan bobot umbi talas seberat 370 g tanaman ${ }^{-1}$ (Sitompul, 2018). Menurut Sitepu (2007) penggunaan pupuk kalium pada kentang berpengaruh nyata terhadap bobot umbi sampel ${ }^{-1}$ dan bobot umbi plot $^{-1}$ namun berpengaruh tidak nyata terhadap tinggi tanaman kentang. Berdasarkan hasil yang telah diuraikan, maka harus dilakukann penelitian mengenai pengaruh dari dosis kompos dan dosis pupuk $\mathrm{KCl}$ terhadap pertumbuhan dan hasil tanaman talas.

\section{METODOLOGI PENELITIAN}

\section{Tempat dan Waktu}

Penelitian ini telah dilaksanakan di Kebun Percobaan II dan Laboratorium Fisiologi Tumbuhan Fakultas Pertanian Universitas Syiah Kuala Darussalam Banda Aceh, pada bulan Maret sampai Agustus 2018.

\section{Alat dan Bahan}

Alat-alaat yang digunnakan pada penelitian ini adalah, cangkul, selang air, timbangan analitik, meteran, oven, dan kamera. Bahan yang digunakan dalam penelitian ini adaalah bibit talas Satoimo sebanyak $5 \mathrm{~kg}$ yang diperoleh dari Badan Diklat Pertanian (BDP) Saree, polibag volume $3 \mathrm{~kg}$ sebanyak 90 helai, polibag volume $15 \mathrm{~kg}$ sebanyak 81 helai, kompos yang terdiri dari kotoran sapi, jerami dan sekam bakar dengan perbandingan $3: 2: 1$ sebanyak 9,1 kg, pupuk Urea 182,25 g, SP36 121,5 g, dan pupuk KCl 182,5 g.

\section{Rancangan Percobaan}

Adapun rancangan Percobaan yang digunakan adalah Rancangan Acak Kelompok (RAK) pola faktorial $3 \times 3$ dengan 3 ulangan. Faktor yanng diteliti yaitu pengaruh dosis pupuk kompos dan pupuk kalium. Dosis pupuk kompos (P) terdapat dari 3 taraf, yaitu:

$\mathrm{P}_{1}=20$ ton ha ${ }^{-1}\left(150 \mathrm{~g} \mathrm{polibag}^{-1}\right) \mathrm{P}_{2}=30$ ton $\mathrm{ha}^{-1}\left(225 \mathrm{~g} \mathrm{polibag}^{-1}\right) \mathrm{P}_{3}=40$ ton ha ${ }^{-1}(300 \mathrm{~g} \mathrm{p}$ libag $\left.^{-1}\right)$ Dosis pupuk KCl $(\mathrm{K})$ terdapat dari tiga taraf, yaitu: $\mathrm{K}_{1}=200 \mathrm{~kg} \mathrm{ha}^{-1} \quad\left(1,5 \mathrm{~g} \mathrm{polibag}^{-1}\right)$ $\mathrm{K}_{2}=300 \mathrm{~kg} \mathrm{ha}^{-1}\left(2,25 \mathrm{~g} \mathrm{polibag}^{-1}\right) \mathrm{K}_{3}=400 \mathrm{~kg} \mathrm{ha}^{-1}\left(3 \mathrm{~g} \mathrm{polibag}^{-1}\right)$.

\section{Pelaksanaan Penelitian}

\section{Persiapan Media dan Penanaman}

Disiapkan campuran media semai berupa tanah top soil dan kompos dengan perbandingan $3: 1$ lalu diisi kedalam polibag. Campuran kompos terdiri dari pupuk kandang, sekam padi dan sekam bakar dengan perbandingan 3:2:1 yang diperoleh dari Fakultas Pertanian Universitas Syiah Kuala. Umbi talas yang telah lewat masa dormansi (masa dimana 
mata tunas mulai tumbuh) dengan berat berkisar 20-50 g ditanam di dalam polibag persemaian. Media tanam yang digunakan yaitu campuran lapisan tanah topsoil dan kompos sesuai dengan perlakuan masing-masing yaitu 20, 30, 40 ton $\mathrm{ha}^{-1}$. Campuran media tanam tersebut dimasukkan kedalam polibag volume $15 \mathrm{~kg}$ yang sudah diberi label perlakuan. Bibit yang telah tumbuh daun sebanyak 2 helai dipindahkan kedalam polibag penanaman. Penanaman dilakukan dengan cara membuat lubang tanam dan meletakkan bibit talas secara tegak lurus ditengah-tengah lubang, kemudian ditimbun dengan tanah sampai tanaman berdiri tegak. Pemindahan bibit dilakukan pada pagi ataupun sore hari untuk mengurangi penguapan yang tinggi.

\section{Pemeliharaan}

Pemeliharaan tanaman yang dilakukan meliputi penyiraman, pemyulaman, pemupukan dan pengendalian hama dan penyakit. penyiraman dilakukan pada pagi dan sore hari atau tergantung pada kondisi lapangan. Pemupukan diberikan pada 1 minggu setelah pindah tanam. Pada tanaman talas pupuk dasar yang diberikan yaitu Urea sebanyak $300 \mathrm{~kg} \mathrm{ha}^{-}$ 1, SP36 sebanyak $200 \mathrm{~kg} \mathrm{ha}^{-1}$ dan $\mathrm{KCl}$ yang diberikan sesuai perlakuan yaitu $200,300,400 \mathrm{~kg}$ $\mathrm{ha}^{-1}$. Penyiangan gulma dan pembumbunan dilakukan 2 minggu sekali, pada umur tanaman 4 , $6,8,10,12$ MST. Pengendalian hama dan penyakit dilakukan apabila timbul gejala serangan hama dan penyakit dengan menyemprotkan Decis sebanyak $1 \mathrm{ml} \mathrm{liter-1}$ (bahan aktif Eltametrin).

\section{Panen}

Pemanenan talas dilakukan pada 16 MST atau ketika tanaman memiliki ciri-ciri untuk dipanen. Adapun ciri-ciri tanaman siap panen yang yaitu ditandai dengan daun menguning, layu, ataupun mengering.

\section{Parameter yang diamati}

Pengukuran tinggi tanaman dilakukan dengan cara mengukur dari pangkal batang utama sampai titik tumbuh tanaman. Perhitungan jumlah daun dilakukan dengan cara menghitung jumlah daun pada setiap tanaman dengan satuan helai. Pengukuran tinggi dan jumlah daun tanaman talas dilakukan pada saat tanaman berumur 2, 4, 6, 8, 10 dan 12 MST. Diameter batang diukur di bagian batang dengan menggunakan jangka sorong. Pengukuran dilakukan pada umur 12 MST. Bobot berangkasan basah dihitung setelah tanaman dipanen yaitu dengan cara menimbang biomassa tanaman tanpa umbi. Bobot berangkasan kering tanaman tanpa umbi dilakukan dengan cara mengovenkan selama $3 \times 24$ jam dengan suhu $70^{\circ} \mathrm{C}$. Setelah biomassa diovenkan, lalu ditimbang dengan menggunakan timbangan analitik. Bobot umbi basah dilakukan dengan cara menimbang berat umbi setelah panen. Pengamatan jumlah umbi dilakukan dengan cara menghitung jumlah umbi pada setiap tanaman. Diameter umbi diukur pada bagian tengah dari umbi dengan menggunakan jangka sorong

\section{HASIL DAN PEMBAHASAN}

Hasil analisis ragam menunjukkan bahwa perlakuan dosis kompos berpengaruh nyata terhadap jumlah daun tanaman talas umur 2 dan 10 MST, bobot umbi basah, dan jumlah umbi tanaman talas. Dosis kompos tidak berpengaruh nyata terhadap tinggi tanaman umur 2, 4, 6, 8, 10 dan 12 MST, jumlah daun tanaman talas pada umur 4, 6, 8, dan 12 MST, serta terhadap bobot berangkasan basah, bobot berangkasan kering, diameter umbi, dan diameter batang tanaman talas. Pengaruh perlakuan dosis kompos terhadap pertumbuhan dan hasil tanaman talas dapat dilihat pada Tabel 1 . 
Pada jumlah daun pada umur 2 MST dan jumlah umbi tanaman talas terbanyak dijumpai pada perlakuan dosis kompos 40 ton $\mathrm{ha}^{-1}\left(\mathrm{P}_{3}\right)$ yang berbeda nyata dengan perlakuan lainnya. Jumlah daun tanaman talas pada umur 10 MST terbanyak dijumpai pada perlakuan dosis kompos 20 ton $\mathrm{ha}^{-1}\left(\mathrm{P}_{1}\right)$ yang berbeda tidak nyata dengan perlakuan dosis kompos 30 ton ha $\mathrm{h}^{-1}\left(\mathrm{P}_{2}\right)$ dan berbeda nyata dengan perlakuan dosis $40\left(\mathrm{P}_{3}\right)$ ton ha ${ }^{-1}$. Bobot umbi basah lebih berat dijumpai pada perlakuan dosis kompos $\left(\mathrm{P}_{2}\right)$ ton ha ${ }^{-1} 30$ yang berbeda tidak nyata dengan perlakuan lainnya. Pada tinggi tanaman umur 2, 6, 8, 10, dan $12 \mathrm{MST}$, jumlah daun pada umur 6 MST, dan diameter umbi tanaman talas cenderung lebih tinggi dijumpai pada perlakuan dosis kompos 40 ton $\mathrm{ha}^{-1}\left(\mathrm{P}_{3}\right)$ meskipun secara statistik berbeda tidak nyata terhadap perlakuan lainnya. Tinggi tanaman dan jumlah daun pada umur 4 MST, serta bobot berangkasan basah tanaman talas cenderung lebih baik dijumpai pada perlakuan dosis kompos 20 ton $\mathrm{ha}^{-1}\left(\mathrm{P}_{1}\right)$, meskipun secara statistik berbeda tidak nyata terhadap perlakuan lainnya. Pada jumlah daun umur 8 dan 12 MST, diameter batang serta bobot berangkasan kering tanaman talas cendeung lebih tinggi dijumpai pada perlakuan dosis kompos 30 ton ha ${ }^{-1}\left(\mathrm{P}_{2}\right)$, meskipun secara statistik berbeda tidak nyata terhadap perlakuan lainnya.

Tabel 1. Pengaruh dosis kompos terhadap pertumbuhan dan hasil tanaman talas

\begin{tabular}{|c|c|c|c|c|c|}
\hline \multirow{2}{*}{\multicolumn{2}{|c|}{ Parameter yang diamati }} & \multicolumn{3}{|c|}{ Dosis Kompos (ton ha-1) } & \multirow{2}{*}{$\begin{array}{l}\text { BNT } \\
0,05\end{array}$} \\
\hline & & 20 & 30 & 40 & \\
\hline \multirow[t]{6}{*}{ Tinggi Tanaman $(\mathrm{cm})$} & $2 \mathrm{MST}$ & 31,67 & 32,04 & 32,26 & \\
\hline & $4 \mathrm{MST}$ & 43,52 & 42,04 & 43,01 & \\
\hline & $6 \mathrm{MST}$ & 59,26 & 57,81 & 60,15 & \\
\hline & $8 \mathrm{MST}$ & 66,56 & 67,26 & 68,70 & \\
\hline & $10 \mathrm{MST}$ & 69,59 & 70,74 & 72,26 & \\
\hline & $12 \mathrm{MST}$ & 70,44 & 71,11 & 72,81 & \\
\hline \multirow[t]{6}{*}{ Jumlah Daun (helai) } & $2 \mathrm{MST}$ & $2,56 \mathrm{a}$ & $2,82 \mathrm{~b}$ & $2,89 \mathrm{c}$ & 0,02 \\
\hline & $4 \mathrm{MST}$ & 3,85 & 3,85 & 3,67 & \\
\hline & $6 \mathrm{MST}$ & 4,56 & 4,37 & 4,70 & \\
\hline & $8 \mathrm{MST}$ & 4,19 & 4,30 & 4,15 & \\
\hline & $10 \mathrm{MST}$ & $3,81 \mathrm{~b}$ & $3,96 \mathrm{~b}$ & $3,44 \mathrm{a}$ & 0,34 \\
\hline & $12 \mathrm{MST}$ & 3,70 & 4,04 & 3,81 & \\
\hline \multicolumn{2}{|l|}{ Diameter Batang (mm) } & 36,29 & 36,51 & 35,63 & \\
\hline \multicolumn{2}{|c|}{ Bobot Berangkasan Basah (g) } & 346,39 & 335,97 & 321,21 & \\
\hline \multicolumn{2}{|c|}{ Bobot Berangkasan Kering (g) } & 107,07 & 109,29 & 102,59 & \\
\hline \multicolumn{2}{|c|}{ Jumlah Umbi (buah) } & $13,19 \mathrm{a}$ & $13,44 \mathrm{a}$ & $15,89 \mathrm{~b}$ & 2,02 \\
\hline \multicolumn{2}{|l|}{ Bobot Umbi Basah (g) } & $258,11 \mathrm{a}$ & $268,60 \mathrm{ab}$ & $305,31 \mathrm{~b}$ & 38,81 \\
\hline \multicolumn{2}{|l|}{ Diameter Umbi $(\mathrm{g})$} & 30,95 & 30,80 & 31,58 & \\
\hline
\end{tabular}

Keterangan : Angka yang diikuti oleh huruf yang sama pada baris yang sama berbeda tidak nyata pada taraf $5 \%$ (Uji BNT 0,05 ).

Perlakuan Dosis Pupuk KCl Terhadap Pertumbuhan dan Hasil Tanaman Talas

Hasil analisis ragam menunjukkan bahwa pemberian pupuk $\mathrm{KCl}$ berpengaruh nyata terhadap tinggi tanaman talas umur 2 MST, jumlah daun tanaman talas umur 4 MST, bobot berangkasan basah, jumlah umbi dan bobot umbi basah tanaman talas, serta berpengaruh tidak nyata terhadap tinggi tanaman umur 4, 6, 8, 10, dan 12 MST, jumlah daun umur 2, 6, 8, 10 dan 12 MST, diameter batang, bobot berangkasan kering, dan diameter umbi tanaman talas. Pengaruh perlakuan dosis pupuk $\mathrm{KCl}$ terhadap pertumbuhan dan hasil tanaman talas dapat dilihat pada Tabel 3. 
Pada tinggi tanaman pada umur 2 MST dan jumlah daun pada umur 4 MST tanaman talas lebih tinggi dijumpai pada pelakuan dosis pupuk $\mathrm{KCl} 300 \mathrm{~kg} \mathrm{ha}^{-1}\left(\mathrm{~K}_{2}\right)$ yang berbeda tidak nyata dengan perlakuan lainnya. Bobot berangkasan basah terberat dijumpai pada perlakuan dosis pupuk $\mathrm{KCl} 300 \mathrm{~kg} \mathrm{ha}^{-1}\left(\mathrm{~K}_{2}\right)$, yang berbeda nyata dengan perlakuan lainnya. Jumlah umbi dan bobot umbi basah tanaman talas tertinggi dijumpai pada pada perlakuan dosis pupuk $\mathrm{KCl} 400 \mathrm{~kg} \mathrm{ha}^{-1}\left(\mathrm{~K}_{3}\right)$, yang berbeda nyata dengan perlakuan lainnya. Tinggi tanaman pada umur 4 dan 10 MST, jumlah daun umur 2, 10 dan 12 MST, bobot berangkasan kering, dan diameter umbi tanaman talas cenderung lebih tinggi dijumpai pada perlakuan dosis pupuk $\mathrm{KCl} 400 \mathrm{~kg} \mathrm{ha}^{-1}\left(\mathrm{~K}_{3}\right)$, meskipun secara statistik berbeda tidak nyata terhadap perlakuan lainnya. Tinggi tanaman pada umur 6, 8, dan 12 MST serta diameter batang tanaman talas cenderung lebih tinggi dijumpai pada perlakuan dosis pupuk $\mathrm{KCl} 300 \mathrm{~kg} \mathrm{ha}$ ${ }^{1}\left(\mathrm{~K}_{2}\right)$, meskipun secara statistik berbeda tidak nyata terhadap perlakuan lainnya. Pada jumlah daun tanaman talas pada umur 6 dan 8 MST cenderung lebih tinngi dijumpai pada perlakuan dosis pupuk $\mathrm{KCl} 200 \mathrm{~kg} \mathrm{ha}^{-1}\left(\mathrm{~K}_{1}\right)$, meskipun secara statistik berbeda tidak nyata terhadap perlakuan lainnya.

Tabel 2. Pengaruh perlakuan dosis pupuk $\mathrm{KCl}$ terhadap pertumbuhan dan hasil tanaman talas

\begin{tabular}{|c|c|c|c|c|c|}
\hline \multirow{2}{*}{\multicolumn{2}{|c|}{ Parameter yang diamati }} & \multicolumn{3}{|c|}{ Dosis Pupuk $\mathrm{KCl}\left(\mathrm{kg} \mathrm{ha}^{-1}\right)$} & \multirow{2}{*}{$\begin{array}{l}\text { BNT } \\
0,05\end{array}$} \\
\hline & & 200 & 300 & 400 & \\
\hline \multirow[t]{6}{*}{ Tinggi Tanaman $(\mathrm{cm})$} & $2 \mathrm{MST}$ & $30,29 \mathrm{a}$ & $31,74 \mathrm{ab}$ & $33,30 \mathrm{~b}$ & 1,89 \\
\hline & $4 \mathrm{MST}$ & 40,44 & 43,52 & 46,00 & \\
\hline & $6 \mathrm{MST}$ & 56,89 & 61,77 & 58,96 & \\
\hline & $8 \mathrm{MST}$ & 63,22 & 71,33 & 71,33 & \\
\hline & $10 \mathrm{MST}$ & 66,78 & 72,78 & 73,04 & \\
\hline & $12 \mathrm{MST}$ & 66,81 & 74,48 & 73,07 & \\
\hline \multirow[t]{6}{*}{ Jumlah Daun (helai) } & $2 \mathrm{MST}$ & 2,67 & 2,74 & 2,85 & \\
\hline & $4 \mathrm{MST}$ & $3,56 \mathrm{a}$ & $3,78 \mathrm{ab}$ & $3,96 \mathrm{~b}$ & 0,27 \\
\hline & $6 \mathrm{MST}$ & 4,74 & 4,52 & 4,37 & \\
\hline & $8 \mathrm{MST}$ & 4,37 & 4,15 & 4,11 & \\
\hline & $10 \mathrm{MST}$ & 3,74 & 3,70 & 3,78 & \\
\hline & $12 \mathrm{MST}$ & 3,81 & 3,81 & 3,93 & \\
\hline \multicolumn{2}{|l|}{ Diameter Batang (mm) } & 35,10 & 37,90 & 35,42 & \\
\hline \multicolumn{2}{|c|}{ Bobot Berangkasan Basah (g) } & $325,70 \mathrm{a}$ & $359,29 \mathrm{~b}$ & $318,58 \mathrm{a}$ & 32,26 \\
\hline \multicolumn{2}{|c|}{ Bobot Berangkasan Kering (g) } & 105,82 & 105,51 & 107,62 & \\
\hline \multicolumn{2}{|c|}{ Jumlah Umbi (buah) } & $13,33 \mathrm{a}$ & $13,07 \mathrm{a}$ & $16,11 \mathrm{~b}$ & 2.02 \\
\hline \multicolumn{2}{|l|}{ Bobot Umbi Basah (g) } & $260,85 \mathrm{a}$ & $265,17 \mathrm{a}$ & $332,01 \mathrm{~b}$ & 38,81 \\
\hline \multicolumn{2}{|l|}{ Diameter Umbi $(\mathrm{g})$} & 30,84 & 31,02 & 31,46 & \\
\hline
\end{tabular}

Keterangan : Angka yang diikuti oleh huruf yang sama pada baris yang sama berbeda tidak nyata pada taraf $5 \%$ (Uji BNT 0,05$)$.

\section{Pembahasan}

\section{Pengaruh Dosiis Kompos terhadap Pertumbuhan dan Hasil Tanaman Talas}

Hasil analisis ragam menunjukkan bahwa dosis kompos berpengaruh nyata terhadap pertumbuhan dan hasil tanaman talas. Semakin tinggi dosis kompos yang diberikan maka semakin baik pula pertumbuhan dan hasil tanaman talas baik pada fase vegetatif maupun reproduktif. Pertumbuhan dan hasil tanaman talas terbaik dijumpai pada dosis kompos 40 ton $\mathrm{ha}^{-1}$. Kompos berfungsi untuk meningkatkan kesuburan tanah, kapasitas penyerapan air oleh 
tanah, aktivitas mikroba tanah, kualitas hasil panen, ketersediaan hara di dalam tanah, serta kompos dapat berfungsi untuk memperbaiki struktur dan karakteristik tanah, menyediakan hormon dan vitamin bagi tanaman, serta dapat menekan pertumbuhan/serangan penyakit tanaman. Hal ini sesuai dengan pernyataan Tangkoonboribun et al. (2007) dengan penambahan bahan organikk ke dalam tanah diharapkan dapat memperbaiki kualitas fisik tanah, meningkatkan ketersediaan hara dalam tanah, meningkatkan kemampuan tanah menahan air dan mampu memperbaiki pertumbuhan tanaman.

Menurut Setyorini et al. (2006) Fungsi utama dari kompos adalah untuk memperbaiki kualitas kesuburan fisik tanah dimana struktur tanah yang semula padat dapat menjadi gembur sehingga mempermudah pengolahan tanah. Kompos dapat memperbaiki sifat kimia tanah dan mengandung unsur hara makro dan mikro meskipun dalam jumlah yang relatif sedikit $(\mathrm{N}, \mathrm{P}$, $\mathrm{K}, \mathrm{Ca}, \mathrm{Mg}, \mathrm{Zn}, \mathrm{Cu}, \mathrm{B}, \mathrm{Zn}, \mathrm{Mo}$, dan $\mathrm{Si}$ ), serta kompos juga dapat memperbaiki sifat biologi tanah. Kompos banyak mengandung mikroorganiksme (fungi, bakteri dan alga). Hasil penelitian Wahyana et al. (2017) pemberian kompos/bokashi daun kacang hijau 40 ton/ha (setara $12,5 \mathrm{~kg} /$ petak) berpengaruh pada bobot kering total per tanaman pada umur $40 \mathrm{HST}$ pada dinamika tumbuh bawang merah varietas Lembah Palu.

Jumlah dan bobot umbi tanaman talas sangat dipengaruhi oleh banyak sedikitnya asimilat yang dihasilkan oleh tanaman. Jumlah asimilat yang kecil, akan menghasilkan bobot umbi yang kecil dan sebaliknya jumlah asimilat yang besar akan menghasilkan bobot umbi yang besar juga. Hal ini sesuai dengan pernyataan Irawan et al. (2017) yang menyatakan bahwa asimilat berfungsi sebagai energi pertumbuhan untuk menghasilkan umbi bawang merah, sehingga banyak sedikitnya umbi yang terbentuk akan sangat dipengaruhi oleh banyak sedikitnya asimilat yang dihasilkan. Pada saat asimilat yang dihasilkan rendah, maka jumlah maupun bobot umbi yang dihasilkan juga rendahHasil penelitian Nagano et al. (2016), dimana perlakuan dosis kompos berpengaruh nyata pada parameter bobot umbi segar tanaman talas dengan perlakuan kompos daun sampah Universitas Brawijaya ( sebanyak 125\% (7,56 ton $\mathrm{ha}^{-1}$ ) yang memberikan hasil panen umbi mencapai 12,77 ton ha ${ }^{-1}$. Berdasarkan hasil penelitian Nagano dan Suminarti (2015) didapatkan bahwa jumlah umbi tanaman talas terbanyak pada aplikasi kompos sampah kota dosis 12,5 ton ha ${ }^{-1}$ dengan rata-rata 20,33 buah dengan rerata bobot umbi basah per tanaman sebesar 336,32 $\mathrm{g} \mathrm{tanaman}^{-1}$.

\section{Pengaruh Dosis Pupuk KCl pada Pertumbuhan dan Hasil Tanaman Talas}

Hasil analisis ragam menunjukkan bahwa pertumbuhan tanaman talas terbaik dijumpai pada dosis pupuk $\mathrm{KCl} 300 \mathrm{~kg} \mathrm{ha}^{-1}$. Hal ini diduga karena pada dosis pupuk $\mathrm{KCl} 300 \mathrm{~kg} \mathrm{ha}^{-1}$ sudah mampu mencukupi kebutuhan unsur hara $\mathrm{K}$ pada tanaman talas, sehingga proses metabolisme tanaman talas menjadi baik. Kalium berperan sebagai pengatur proses fisiologi tanaman seperti fotosintetis, akumulasi, translokasi, transportasi karbohidrat, membuka dan menutupnya stomata, atau mengatur distribusi air dalam jaringan dan sel. Menurut Taufiq (2002), unsur hara K berfungsi sebagai media yang membawa unsur hara dari akar ke daun dan mentranslokasi asimilat dari daun ke seluruh jaringan tanaman sehingga dibutuhkan unsur $\mathrm{K}$ yang optimal agar proses translokasi unsur hara ataupun asimilasi dalam tanaman dapat berlangsung dengan baik untuk pertumbuhan awal tanaman. Hasil penelitian Sitompul (2018), 
penggunaan pupuk $\mathrm{KCl}$ dengan dosis $300 \mathrm{~kg} \mathrm{ha}^{-1}$ dapat meningkatkan tinggi tanaman talas pada umur 4 MST.

Menurut Pratiwi (2014) apabila luas daun dan jumlah daun yang dihasilkan pada tanaman talas baik maka akan menghasilkan bobot berangkasan basah tanaman talas lebih berat. Bobot berangkasan basah tanaman merupakan fungsi dari organ tanaman seperti jumlah daun, jumlah cabang maupun luas daun. Apabila luas dan jumlah daun yang dihasilkan banyak, maka kapasitas dan kemampuan tanaman untuk menghasilkan asimilat juga banyak. Banyaknya asimilat yang terbentuk akan digunakan untuk menambah ukuran dan jumlah bobot berangkasan basah. Hasil penelitian menunjukkan bahwa pupuk $\mathrm{KCl}$ berpengaruh nyata terhadap bobot berangkasan tanaman talas. Dosis pupuk $\mathrm{KCl}$ terbaik dijumpai pada dosis pupuk $\mathrm{KCl} 300 \mathrm{~kg} \mathrm{ha}^{-1}$ dengan menghasilkan rata-rata bobot berangkasan basah tanaman talas sebesar 359,29 tanaman ${ }^{-1}$. Hasil penelitian ini lebih tinggi dari hasil penelitian Suminarti (2010) pupuk Kalium berpengaruh nyata terhadap bobot berangkasan tanaman talas. Dosis dosis pupuk $\mathrm{KCl}$ terbaik dijumpai pada dosis pupuk Kalium $200 \mathrm{~kg} \mathrm{ha}^{-1}$ dengan menghasilkan rata-rata bobot berangkasan basah tanaman talas sebesar 191,25 g tanaman $^{-1}$.

Hasil penelitian menunjukkan bahwa umbi tanaman talas terbaik dijumpai pada dosis pupuk $\mathrm{KCl} 400 \mathrm{~kg} \mathrm{ha}^{-1}$. Hal ini diduga bahwa tanaman talas memerlukan pasokan pupuk $\mathrm{KCl}$ yang tinggi untuk proses pembentukan dan pembesaran umbi. Kalium pada tanaman terlibat dalam proses membuka dan menutupnya stomata, distribusi air dan transportasi karbohidrat. Pada tanaman talas unsur $\mathrm{K}$ sangat diperlukan untuk proses fotosintesis dan juga membantu pembentukan dan pembesaran umbi. Hal ini sesuai dengan pernyataan Rulina (2010) yang menyatakan bahwa Kalium dapat meningkatkan aktivitas fotosintesis namun pengaruhnya lebih besar terhadap proses pembentukan umbi dari pada pertumbuhan batang, daun dan penambahan luas daun. Menurut Prawinata et al. (1981), berlangsungnya proses fotosintesis yang baik maka akan menghasilkan fotosintat yang. Menurut Lubis dan Suwarto (2018) semakin banyak jumlah $\mathrm{K}$ didalam tanah maka semakin banyak pula $\mathrm{K}$ yang diserap oleh tanaman talas. Berdasarkan hasil penelitian Sitompul (2018) menunjukkan bahwa dosis pupuk Kalium berpengaruh nyata terhadap bobot umbi tanaman talas. Pertumbuhan dan hasil terbaik dijumpai pada dosis pupuk Kalium $400 \mathrm{~kg} \mathrm{ha}^{-1}$ dengan menghasilkan rata-rata bobot umbi tanaman talas sebesar 370,00 g.

\section{KESIMPULAN DAN SARAN}

\section{Simpulan}

Hasil penelitian menunjukkan bahwa dosis kompos berpengaruh nyata terhadap jumlah daun umur 2 dan 10 MST, jumlah umbi, dan bobot umbi basah tanaman talas. Pertumbuhan dan hasil tanaman talas terbaik dijumpai pada dosis kompos 40 ton $\mathrm{ha}^{-1}$. Hasil penelitian menunjukkan bahwa dosis pupuk $\mathrm{KCl}$ berpengaruh nyata terhadap tinggi tanaman talas umur 2 MST, jumlah daun pada umur 4 MST, bobot berangkasan basah, jumlah umbi dan bobot umbi basah tanaman talas. Pertumbuhan tanaman talas terbaik dijumpai pada dosis pupuk $\mathrm{KCl}$ $300 \mathrm{~kg} \mathrm{ha}^{-1}$ dan hasil tanaman talas terbaik dijumpai pada dosis $\mathrm{KCl} 400 \mathrm{~kg} \mathrm{ha}^{-1}$.

\section{Saran}

Perlu dilakukan penelitian lebih lanjut dengan melakuan penanaman dibedengan apabila bibit tersedia dan dilakukan pada awal musim hujan. 


\section{DAFTAR PUSTAKA}

Anwar, S. dan U. Sudadi. 2013. Kimia Tanah. IPB Press. Bogor.

Biotrop. 2013. South East Asian Regional Centre for Tropical Biology Invasive Alien Species. https://www.biotrop.org. [1 Maret 2018].

Budiyanto, S. 2009. Dukungan iptek bahan pangan pada pengembangan tepung lokal. Buletin Pangan. 54(18): 55-67.

Corwin, E. J. 2007. Buku Saku Patofisiologi. Kedokteran EGC. Jakarta.

Hidayat, A. A. A. 2006. Pengantar Kebutuhan Dasar Manusia Aplikasi Konsep dan Proses Keperawatan. Salemba Medika. Jakarta.

Febrinugroho, 2009. manfaat abu sekam padi. http:// febrynugroho. wordpress.co/2009/ 04/3manfaat-abu-sekam-padi/. ( 14 April 2018).

Irawan, D., Idwar. I. dan Murniati. 2017. Pengaruh pemupukan N, P dan K terhadap pertumbuhan dan hasil bawang merah (Allium ascalonicum. L) varietas bima Brebes dan Thailand di tanah Ultisol. Jurnal Online Mahasiswa Pertanian Universitas Riau. 4(1): 2 .

Lubis, L. W. K. dan Suwarto. 2018. Pengaruh jarak tanam dan dosis pupuk kalium terhadap pertumbuhan dan produksi talas Belitung (Xanthosoma sagittifolium (L.)). Buletin Agrohorti. 6(1): 87-89.

Mulyono. 2014. Membuat Mol dan Kompos dari Sampah Rumah Tangga. PT. Agro Media Pustaka. Jakarta.

Nagano, M. dan Duminarti. 2015. Respon tanaman talas (Colocasia esculenta (L.) Schott var. antiquorum) pada berbagai jumlah frekuensi pemberian air. Life Science. 5(3). 340.

Nagano, M., S. Sunaryo dan N. E. Suminarti. 2016. Studi tentang aplikasi kompos UB pada pertumbuhan dah hasil tanaman talas (Colocasia esculenta (L.) Schott var. Antiquorum) yang ditanaman di lahan kering pada musim kemarau. Life Science. 7(4): 570-572.

Onwueme, I. C. 1978. The Tropical Tuber Crops. Jhon Willey \& Sons, New York.

Prana, M. S. 2002. Studi Biologi Pembungaan pada Talas (Colocasia esculenta (L.) Schott). Biodiversitas. 8(1): 63.66.

Pratiwi, S. H. 2014. Pertumbuhan dan hasil tanaman talas (Colocasia esculenta (L.) Schott var. Antiquorum) pada berbagai ukuran umbi dan jumlah daun. Tesis. Program Pasca Sarjana Fakultas Pertanian Universitas Brawijaya. Malang.

Putra, S. dan P. Kardisi. 2011. Pengaruh pupuk kalium terhadap peningkatan hasil ubi jalar varietas Narutokintoki di lahan sawah. Jurnal Agrin. 15(2): 133-140.

Pradana, R. E., N. Rahmawati dan Martati. 2016. Pengaruh pemberian pupuk organikk terhadap pertumbuhan dan produuksi ubi jalar ungu (Ipomea batatas L.). Jurnal Agroekoteknologi. 4(4) : 2215-2216. 
Prawinata W.S., Harran dan Tjondronegoro. 1981. Dasar-dasar Fisiologi Tumbuhan. Departemen Botani IPB. Bogor.

Prihmantoro, H. dan Y. H. Indriani. 2003. Hidroponik Sayuran Semusim untuk Hobi dan Bisnis. Penebar Swadaya. Jakarta.

Purwono dan P. Heni. 2007. Budidaya 8 jenis Tanaman Pangan Unggul. Penebar Swadaya. Bogor.

Setyorini, D., S. Rasti dan A. Kosman. 2006. Kompos. Balai Besar Litbang Sumberdaya Lahan Pertanian Badan Penelitian dan Pengembangan Pertanian. Bogor.

Richana, N. 2012. Ubi Kayu dan Ubi Jalar. Nuansa Cendikiawa. Bandung.

Rulina, D. 2010. Pengaruh pemberian dosis pupuk kalium dan macam cara peletakan stek terhadap pertumbuhan dan hasil ubi jalar (Ipomoea batatas (L.) Lam.). Skripsi. Fakultas Pertanian Universitas Sebelas Maret. Surakarta.

Sarwono. B. 2005. Ubi Jalar. Penebar Swadaya. Jakarta.

Sitepu, R. 2007. Respon pertumbuhan dan produksi tanaman kentang (Solanum tuberosum L.) terhadap pupuk kalium dan paklobutrazol. Skripsi. Universitas Sumatera Utara. Medan.

Sitompul, D. R. 2018. Pengaruh dosis pupuk kandang dan pupuk kalium terhadap pertumbuhan dan hasil Tanaman talas. Skripsi. Fakultas Pertanian Universitas Syiah Kuala. Banda Aceh.

Sukaryorini dan Arifin, 2007. Pengaruh modelling macam tanaman terhadap nilai erosi di lahan pertanian. Pertanian Mapeta. 2(9): 96-100.

Suminarti, N. E. 2010. Pengaruh pemupukan N dan K pada pertumbuhan dan hasil tanaman talas yang ditanam di lahan kering. Agrosia. 13 (1): 1-7.

Suminarti, N. E. dan Nagono. 2015. Upaya peningkatan hasil tanaman talas (Colocasia esculenta (L.) Schott var Antiquorum) pada lahan kering melalui aplikasi kompos sampah kota. Life Science. 2(2): 100-109.

Suwahyono, U. 2014. Cara Cepat Buat Kompos dari Limbah. Penebar Swadaya. Jakarta.

Taufiq, A. 2002. Status P dan K lahan kering tanah alfisol pulau Jawa dan Madura serta optimasi pemupukan untuk tanaman kacang tanah. Prossiding Seminar Nasional dan Pertemuan Tahunan Komisariat Daerah Himpunan Ilmu Tanah Indonesia. 16-17 Desember. 94-103.

Tangkoonboribun, R., S. Ruaysoongnern. P. Vityakon. B. Toomsan. M. S. Rao. 2007. Effect of organikc ameliorants to improve soils using sugarcane as a model. XXVI Congres International Society of Sugar Cane Technologists.. Durban. South Africa.

Wahyana, E., H. M. Anshar. dan A. Ete. 2017. Dinamika tumbuhan tanaman bawang merah (Allium cepa L. Kelompok Agregatum) varietas lembah palu dengan pemberian pupuk organikk dan interval pemberian air sistem springkel. Jurnal Agroland. 24(1): 84. 